\title{
The International Movements of Capital and Labour: A Study of Foreign Direct Investment and Migration Flows
}

\author{
Antonio Mihi-Ramirez, Jesús Arteaga-Ortíz, Sara Ojeda-González
}

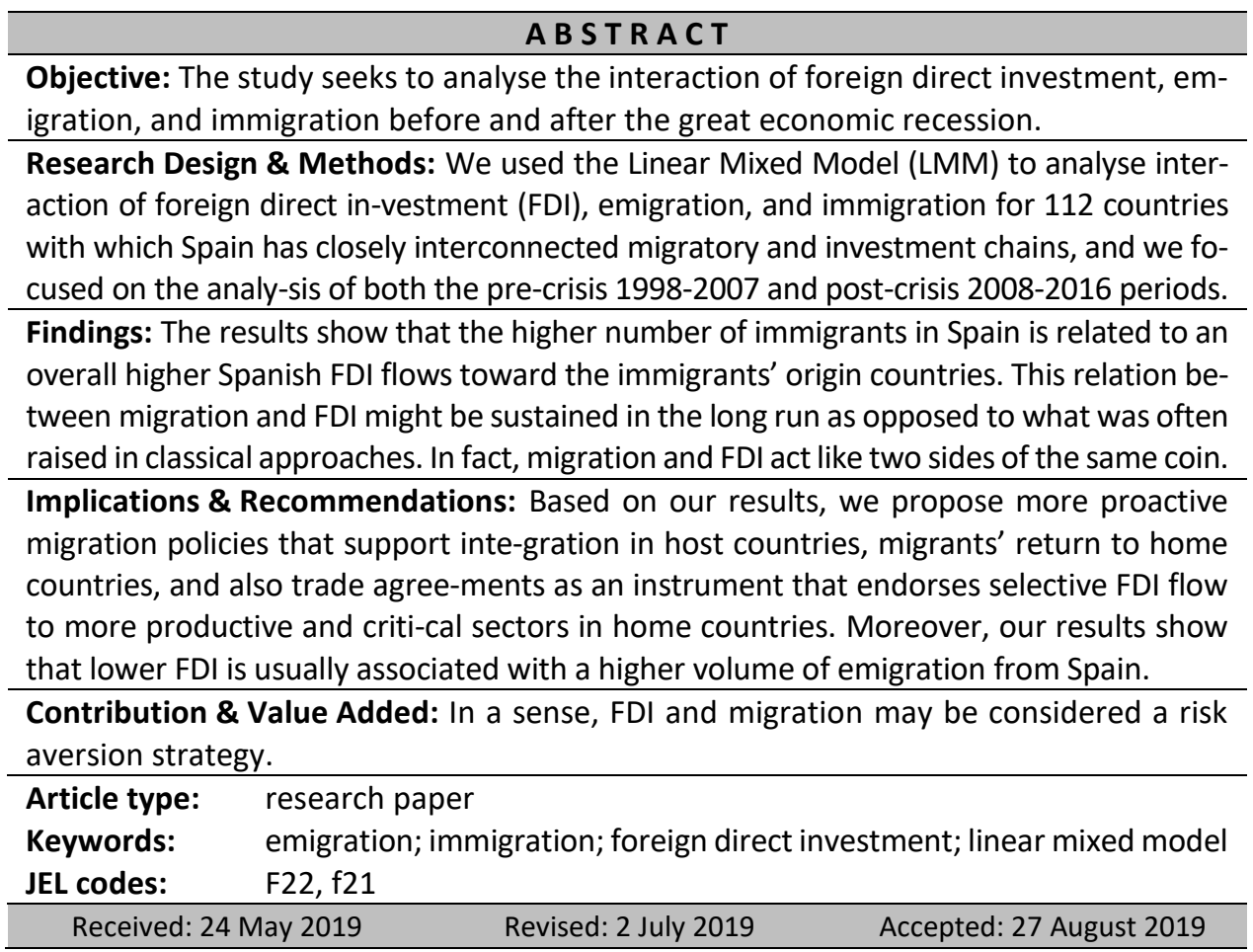

\section{Suggested citation:}

Mihi-Ramirez, A., Arteaga-Ortíz, J., \& Ojeda-González, S. (2019). The International Movements of Capital and Labour: A Study of Foreign Direct Investment and Migration Flows. Entrepreneurial Business and Economics Review, 7(3), 143-160. https://doi.org/10.15678/EBER.2019.070308 


\section{INTRODUCTION}

The contemporary global economy is characterised by international movements of capital and labour (Phyo et al., 2019; Comolli, 2018; Xu \& Sylwester, 2016). Dicken (2003; see also Wallerstein 1974) addresses the relevance of international flows (movements) of capital. In turn, Portes (1997) and later Castles and Miller (2009) highlight the importance of international labour flows. Both movements - foreign direct investment (FDI) and migration intertwine with each other, being directly implicated in the development of the global economy (Le \& Tran-Nam, 2018) and economic convergence (Gandolfi et al., 2017). In any case, they are both deemed to be means of production (Phyo et al., 2019; Sanderson \& Kentor, 2008; Mallampally \& Sauvant, 1999).

Migration and FDI are crucial mechanisms for any economy at any time (Metelski \& Mihi-Ramirez, 2015; Bijak, 2010; Schiff, 1994), but more recently FDI and migratory flows are becoming increasingly important to the economy and enterprises due to intense worldwide changes (Xu \& Sylwester, 2016).

The first decade of the twenty-first century, up till now, is very indicative of the upward trend in mobility factors; i.e. workers, capital. In general, migration flows in OECD countries has increased since the early 1990s, continuing their trend that had already began in rich countries in the early 1980s (Sanderson \& Kentor, 2008). The upward trend of labour migration worldwide is also evident. So is the increasing FDI trend (Mallampally \& Sauvant, 1999).

Therefore, the study of the implications and interactions that arise from the international mobility of workers and capital is always useful, especially in times of major changes in the economy, companies, and society (Xu \& Sylwester, 2016).

As indicated by Sanderson and Kentor (2009), capital flows not only trend upward similarly to labour flows - but the trend also shows its very pronounced nature. Only in the last two decades of the twentieth century, capital flows increased by almost a thousand per cent (UNCTAD, 2005).

Migration flow arises from the existence of certain links between countries of destination and origin. Castles and Miller (2009) highlight colonial ties, foreign trade exchange, and FDI as potential links of this type.

Combes et al. (2005) observe that, when the number of immigrants increases in the country of destination, it is also accompanied by an increase in the inflow of FDI to that country. Buch et al. (2006) and later Javorcik et al. (2011) note that, when immigration increases, the inflow of FDI to the countries of origin of these immigrants also increases. Aubry et al. (2012) show that the growing level of FDI is the cause of immigration to the investor's country. Here, FDI and immigration can be perceived as substitutes. Let us note that Metelski and Mihi-Ramirez (2015) foreground the bidirectionality of labour and capital flows, so that an "investor country" also is a sending country, especially when migrants manage to create networks over time, facilitating the flow of information about business opportunities in their countries of origin while reducing transnational costs (Cuadros et al., 2016; Jayet \& Marchal, 2016; Simone \& Manchin, 2012; Flisi \& Murat, 2011; Docquier \& Lodigiani, 2010).

In our analysis, we noted the following issue that leads to the key question whether there is a variable relationship between sending and receiving countries in the field of immigration, emigration, and FDI. Therefore, the scientific problem of our research is to ex- 
amine the relationship between emigration, immigration, and FDI when economic conditions of sending and receiving countries change over time. We based on the case of Spain, a well-developed country with well-established migration and capital relations with other countries, severely affected by the recent recession. Thus, we expect answers to the following questions: Does an increase in the number of immigrants in Spain translate into an increase in the inflow of FDI to the countries of origin? Do Spanish immigrants choose mainly those destination countries where Spain's FDI is traditionally higher?

The relevance of the raised problem can be better understood by a larger exploration of issues and limitations previously addressed by other scholars. They can be briefly summarised as follows:

- Although the importance of the topic is undeniable, there are few theoretical explanations of the relationship between emigration, immigration, and FDI. Some researchers note that the inflow of FDI to migrants' countries of origin affects emigration only at the initial stage (Javorcik et al., 2011; Buch et al., 2006). Other authors indicate that FDI is significant in the second stage when it reduces differences in wages between countries, also by having a negative or small impact on migration (Gandolfi et al., 2017; Aroca \& Maloney, 2005). Moreover, some studies indicate that there is a two-way relationship between FDI and migration flows, which may be either complementary (Comolli, 2018; Docquier \& Lodigiani, 2010; Schiff, 1994) or substitutive (Sanderson \& Kentor, 2008). However, what happens when the migration process has already started, and FDI is reduced due to economic recession, supply shock, or demand shock?

- Out of many recent theoretical approaches to the matter, none brings any significant confirmation of the link between emigration, immigration, and FDI.

- As Sanderson and Kentor (2008) show, the conceptual and empirical link between international migration and international capital flows remains relatively unexplored. There is usually a two-way interaction between migration and capital flows (Sanderson \& Kentor, 2008). One of them is related to the direct impact of capital flows on the labour market. The latter may result from the impact of FDI on growth, which leads to a significant change in migration flows in the form of indirect impact ( $\mathrm{Xu} \&$ Silvester, 2016). However, what happens when both FDI and economic growth weaken?

The aim of this scientific paper is to examine the relationship between international emigration, immigration, and foreign direct investment - before and after significant changes - in the context of economic recession.

The study is based on the Linear Mixed Model and aims to test the links between immigration, emigration, and FDI between 1998 and 2016. This method is useful for analysing repetitive measurements over time and for taking into account the correlation of responses within the different thematic categories. The results of the research will enable the verification of the hypothesis presented below and will facilitate the drawing of appropriate conclusions and the formulation of practical recommendations.

As for the novelty and theoretical significance of this study, it provides an in-depth review of literature on migration, but it also identifies the most relevant theoretical approaches and issues related to migration and FDI.

The aforementioned overview is the key issue of this paper because knowledge on migration is very fragmented. There are several theories that cover different approaches: 
microeconomics, macroeconomics, sociology, geography, and many others. On the other hand, the relationship between migration and FDI so far received but partial exploration.

For example, there are numerous studies that concern, for instance, the impact of immigration on the economic and social situation of individual countries or the impact of FDI on net migration. However, we should not overlook that there is a lack of studies that would measure migration and FDI by taking into account different theoretical perspectives. On the contrary, our analysis is based on a number of scientific approaches, such as the network migration theory, the world-systems theory, the Heckscher-Ohlin model, the push-pull theory, the migration systems theory, the neoclassical theory, the new economics of migration theory, the theory of motivation for migration decisions, and the theory of cumulative causation.

Existing literature mainly focuses on FDI and immigration for one or more countries and usually only refers to a limited period of time, like one specific year, especially when FDI is growing (Grogger \& Hanson, 2011; Clark \& Pearson, 2007). With this in mind, our empirical study differs in that it examines immigration and emigration in many countries (112 countries) by paying particular attention to changes in immigration, emigration, and FDI processes over time, from 1998 to 2016. This allows us to take into account a much larger number of factors specific to the destination countries by identifying the impact of the analysed variables before and after the recent global economic crisis.

Finally, this article complies with the criteria for a typical structure of scientific research, because it consists of an introduction, background, methodology, discussion, conclusions, and a reference list.

\section{LITERATURE REVIEW AND THEORY DEVELOPMENT}

Capital mobility is the key driver of migration. In this respect, the world-systems theory explains migration processes in terms of interactions between different societies or countries. It argues that migration plays a key role in changing the entire society. The world-systems theory defines migration flows from a global perspective. Flows of mobility factors (i.e. FDI), which are part of international interactions between different countries, tend to cause some disparities in their economic conditions. Consequently, countries with more prosperous economies attract migrants from less dynamic economies (Massey et al., 1993).

Another important current of studies on migration explores the relationship between FDI and migrant networks (Cuadros et al., 2016; Javorcik et al., 2011; Docquier \& Lodigiani, 2010; Buch et al., 2006; Schiff, 1994), which highlights the growing relationship between these variables over time. The network migration theory addresses the key role of personal relationships between immigrants and non-immigrants. In other words, migration flows result from the existence of certain links between destination countries and countries of origin (Simone \& Manchin, 2012). In this sense, Castles and Miller (2009) refer to colonial ties, trade, and FDI as probable links. Burns and Mohapatra (2008) argue that - similarly to international migration - FDI is an important channel for the transfer of technology and knowledge. Moreover, Flisi and Murat (2011, p. 797) show that the impact of immigrants on FDI from less developed countries is as strong as that of immigrants from richer economies. FDI is attracted by networks but not the other way around (Flisi \& Murat, 2011).

Certain explanations regarding the role of the flow of capital investments and its association with migration processes provides the world-systems theory (Wallerstein, 1974), 
which posits that migration is a natural consequence of the evolutions of capitalism and advances of the global market (Bijak, 2010). The demand for basic resources in developed countries causes a flow of capital to less developed countries, but also a higher migration in the opposite way (Massey et al., 1993). However, this approach does not necessarily explain what happens when demand falls in more developed and advanced economies.

FDI, trade, and migration are considered substitutes in the context of the HeckscherOhlin conceptual framework (Markusen, 1983; Mundell, 1957). Mundell (1957, p. 4) argues that the movement of goods "is at least to some extent a substitute for movement of factors of production." However, despite the great progress made with this approach, HeckscherOhlin's view on the flow of international mobility factors - i.e. FDI, trade, remittances, and migration - is controversial, although many scientists claim that this flow may limit migration between rich and poor countries in the long run. It can be argued that rich countries import labour-intensive goods, which results in an increase in the employment of unskilled workers in poor countries. This also implies some direct investment in these poor countries, primarily to adjust their production capacity to the growing demand for goods (Schiff, 1994). As it turns out, higher demand for goods and higher FDI usually lead to a decrease in the outflow of migrant workers. However, Schiff's results (1994) confirm an increase in international migration in the long term - for both sending and receiving countries - which may be interpreted ambiguously. Moreover, Russell and Teitelbaum (1992) along with Gheasi et al. (2013) show that migration and FDI can complement each other. Moreover, more recently, Metelski and Mihi-Ramirez (2015) confirm that the substitutability of migration and FDI occurs only in certain specific circumstances. In turn, Jayet and Marchal (2016) note that this substitutability or complementarity depends on the country's endowments.

According to some neoclassical models - i.e. models based on the basic assumption of the open economy - different channels are often considered substitutes. Some say that the movement of mobility factors like FDI may lead to price equalisation (Gandolfi et al., 2017; Burda, 2004). However, there are also models assuming that such integration factors are complementary; e.g. the Ricardian model.

D'Agosto et al. (2006) study the relationship between FDI inflows and migration flows from developing countries. They find direct and indirect channels of labour demand through which two factors of economic mobility turned out to be substitutes: incoming FDI and migration flows from developing countries. However, let us note that their study yields different results depending on the method used to analyse the aforementioned relationship. In fact, cross-sectional analysis provides arguments for complementarity which is a positive link - while longitudinal analysis supports FDI and migration substitutability, which is a negative relation.

Breitenfellner and Cuaresma (2008) assess the economic impact of the 2004 and 2007 enlargements of the European Union , in particular the increase in the flow of cross-border mobility factors; i.e. labour and capital). In this respect, Tanaka (2017) studies the potential negative impact of immigration on the Japanese labour market (2001-2007) as a consequence of higher FDI. His research shows the emergence of temporary workers at an early stage but, in the long term, their activity began to inch down.

Tomohara (2017) shows that, over time, immigration began to have a negative impact on FDI flows into the country of origin; this was particularly the case for short-term but larger immigration stocks, but also for ethnic networks that generally stimulate FDI flows. 
All in all, several studies show the relationship between FDI in less developed economies and migration flows, but the topic of migration requires a more in-depth analysis of migration and immigration, with particular emphasis on the dynamics of these processes and flows, so researchers must answer the key question: What is the relationship between immigration and FDI over time? And, of course, we should raise a similar question with regard to the relationship between emigration and FDI.

When it comes to the link between immigration and FDI, Gould (1994) shows that higher emigration rate from any sending country usually leads to a higher inbound FDI, which we may substantiate with such reasons as networking, social links, or lower communication costs (Le \& Tran-Nam, 2018; Cuadros et al., 2016; Simone \& Manchin, 2012; Combes et al., 2005).

Buch et al. (2006) examine the relationship between migration and FDI in Germany. Their particular interest is to answer whether and how migration and FDI are associated with each other. Apparently, the stock of inward FDI and that of immigrants can be explained with similar determinants. Higher stocks of inbound FDI are reported in any country that actually hosts a larger foreign population from the same origin country. In other words, if a country receives numerous migrants from any particular country, chances are that it also entails higher capital flows to the sending country. This phenomenon is better known as "the agglomeration effect" (Buch et al., 2006).

Moreover, Schiff (1994) notices that immigrants typically provide their hosts with information about investment opportunities in the source countries, on laws and regulations in these countries, differences in culture and ways of doing businesses, including business contacts, which facilitate the association of business partners. Of course, this is expected to result in an increase in FDI.

More recently, Javorcik et al. (2011) study the impact of immigrants on foreign direct investment (FDI). Their results are similar to those of Buch et al.'s (2006). In a nutshell, the presence of immigrants can stimulate FDI by promoting information flows across international borders. Javorcik et al. (2011) examine the link between the presence of migrants in the USA and US FDI in the countries of origin, taking into account the potential endogeneity concerns. The results show that outward US FDI is positively correlated with the presence of migrants from the host country in the US. In this sense, Cuadros et al. (2016) find that migrants can reduce cross-border investment barriers, especially the effect of financial constraints.

Phyo et al. (2019) show a connection between inward FDI and immigration according to the country's level of development.

Taking into account the earlier considerations, we propose hypothesis 1 :

H1: Immigration is positively associated with FDI in countries behind this FDI flows.

Regarding emigration and FDI, Aroca and Maloney (2005) investigate Mexican exposure to inward FDI, and its response in terms of migration flows. Their findings indicate that greater exposure to FDI attenuates the effect of emigration. The intention of Aroca and Maloney's (2005) study is to provide a quantifiable empirical measurement of the impact of increased FDI on migration processes between Mexico and the USA. They find that - on average - an increase of FDI flow toward Mexico by 100 per cent leads to a decline of emigration by 1.5 to $2 \%$. 
Aubry et al. (2012) show that FDI stimulates migration to host countries at an initial stage, yet later, an equalisation of salaries in sending countries reduces labour market pressures to migrate.

Moreover, others observe that the dynamics of international flows are usually bidirectional (Metelski \& Mihi-Ramirez, 2015), which is why FDI can over time lead both to a higher level of development in sending countries and greater business opportunities for foreign investors. Consequently, foreign workers can migrate much more easily because of the existence of multinational subsidiaries, also due to new business creation opportunities that facilitate establishing businesses, transaction costs reduction, or better knowledge and diffusion of information, associated with migrants' networks in the host country (Munemo, 2017; Simone \& Manchin, 2012). In this case, migration shall result in complementing rather than substituting FDI.

Wang et al. (2013) along with Xu and Sylwester (2016) observe that, in the long run, FDI acts as a deterrent to emigration as it also leads to an increase of domestic incomes. Wang et al. (2013) find that inward FDI in non-OECD countries influences high skill emigration from OECD countries that originates investments. Xu and Sylwester (2016) also show that FDI increases emigration, among other reasons, because of the role played by multinational corporations, i.e. they facilitate information about less developed countries. FDI also reduces transaction costs for potential emigrants. Such FDI would then act as a pull factor, which draws emigrants towards less developed countries.

In turn, the cumulative causation theory indicates several causes for the emergence of different stages of migration waves. One of them is the growing disparity in living standards between re-migrants (returnees) and non-migrants, which is once again contributing to the re-migration of returnees. Yet another cause is the decrease in the de-mand for rural land due to excessive land purchases made mainly by re-migrants. Moreover, re-migrants rarely themselves cultivate purchased land and much rather treat it as an investment of capital or lease it out to professional farmers, which usually leads to increased competition in farm labour through intensified agricultural operations. As a result, smallholder peasants move away in search of sources of additional income because they can no longer cope with competition (Massey et al., 1993). The third cause is the desire to maintain higher standards of living by returnees, which further encourages them to remigrate. The fourth cause is the development of networks that facilitate migration even in the case of less entrepreneurial people, who are initially unwilling to undertake migration and leave their places of residence. The last migration cause is the stigmatization of some commercial activities in receiving countries, which induces employers to search for workers in other countries (Massey et al., 1993).

De Haas (2010) notes that circular cumulative causation theory and migration systems theory have very much in common. They both view the origin and destination as constituent parts of one societal and developmental context. In that sense, both sending and receiving ends contribute to the dynamics of migration.

Phyo et al. (2019) indicate the positive association between inward FDI and emigration flows in the case of relatively less-developed countries.

The above considerations make us propose another hypothesis:

H2: FDI and emigration from investment origin countries (FDI) are negatively associated. 


\section{MATERIAL AND METHODS}

This section explains the empirical analysis to test our hypotheses. Table 1 summarizes the methodology.

Table 1. Description of empirical analysis

\begin{tabular}{|c|c|}
\hline Vabiables & FDI/Emigration/Immigration \\
\hline Method & $\begin{array}{l}\text { Linear Mixed Models (LMMs); (R Core team, 2017; West et al. 2007); 5\% sig- } \\
\text { nificance level and 95\% confidence intervals were obtained foe the estimates. }\end{array}$ \\
\hline Sources & $\begin{array}{l}\text { Migration data was collected from National Statistics of Spain. INE. "Residen- } \\
\text { tial Variation Statistics" and data about FDI by the Ministry of Economy and Fi- } \\
\text { nance of Spain. Datainvex (2018). }\end{array}$ \\
\hline Sample & $\begin{array}{l}112 \text { countries with which Spain has more closely interconnected migratory } \\
\text { and investment chains. }\end{array}$ \\
\hline Period & We focused on pre-crisis $1998-207$ and post-crisis $2008-2016$ reriods. \\
\hline
\end{tabular}

Source: own study.

The models applied to the data were Linear Mixed Models (LMMs), as an appropriate statistical tool to analyse repeated measures over time and to take into account the correlation of responses among subjects (Gardiner et al., 2009). Alternatively, models with and without random effects for each period were checked and discarded as appropriate, based on the goodness of fit measures such as the likelihood ratio test. When comparing Linear Mixed Models (LMMs) with other statistical tools for modelling repeated data, such as Generalised Estimation Equations (GEE) or ANOVA, we preferred to employ the LMM statistical model, which contains both fixed effects and random effects that deal with missing values (West et al., 2007).

For the analysis of how emigration and immigration respond to variations in the FDI, we assumed that there are $n$ independent observations. For each individual $i$, there is a response variable $Y i$ and $p$ covariates $x i=(x i 1, \ldots, x i p) t$, where $x i$ is a vector column of dimension $p<n$. In the classical linear model, it is assumed that $Y i=x t i \beta+\varepsilon i,(1)$ where $\beta$ is a vector column with p parameters, while $\varepsilon$ i satisfies that cii.i.d. $\sim N(0, \sigma 2)$, in which "i.i.d." means "independently and identically distributed." The above equation assumes the regression model as follows:

$\mathrm{Y}=$ (a Fixed + a Random_by_site $)+(\mathrm{b}$ Fixed $+\mathrm{b}$ Random_by_site $) \mathrm{x}$ it means $y=$ (fixedeffect intercept + by-Site random variation in the intercept $)+($ fixed-effect slope + by-Site random variation in the slope) $x x$.

The sample focuses on data on emigration and immigration between countries with which Spain has large migratory and trade exchanges. According to the statistical series of the Spanish National Statistics Institute, INE, "Residential Variations Statistics" cover approximately 112 countries. ${ }^{1}$ The variables analysed are:

\footnotetext{
${ }^{1}$ Albania, Algeria, Andorra, Angola, Argentina, Armenia, Australia, Austria, Bangladesh, Belgium, Benin, Belarus, Bolivia, Bosnia and Herzegovina, Brazil, Bulgaria, Burkina Faso, Cameroon, Canada, Chile, China, Colombia, Congo (Republic of), Cyprus, Congo (Democratic Republic of the), Congo (Democratic Republic of the), Germany, Saudi Arabia, Korea (Republic of), Côte d'Ivoire, Costa Rica, Croatia, Cuba, Denmark, Dominica, Ecuador, Egypt, El Salvador, Estonia, Ethiopia, Finland, France, Gambia, Georgia, Ghana, Greece, Guatemala, Guinea, Guinea, Philippines, Equatorial Guinea, Guinea-Bissau, Honduras, Hungary, India, Slovenia, United States, Iceland, Indonesia,
} 
1. Emigration from Spain to other countries;

2. Immigration from other countries to Spain;

3. FDI from Spain to the countries of the immigrants.

The variables (emigration, immigration, FDI) were cautiously selected by taking into account various migration theories and conceptual frameworks. FDI reflects "the objective of obtaining a lasting interest by an investor in one economy in an enterprise resident in another economy" (Eurostat, 2019, p. 1). Typically, there is a lack of a single and unanimous definition with respect to the migration phenomenon (Mihi-Ramírez et al., 2013).The most frequently referred definitions of immigration and emigration are provided by the Official Journal of the European Union (OJEU, 2007, p. 1), which defines emigration/migration (EM) as "the action by which a person, having previously been usually resident in the territory of a Member State, ceases to have his or her usual residence in that Member State country for a period that is, or is expected to be, of at least 12 months."

The migration flows data (for the purpose of this research) were collected from National Statistics of Spain, INE, and data about FDI from the Ministry of Economy and Finance of Spain, Datainvex (2018), spanning the period from 1998 to 2016 . $^{2}$

The statistical analysis was conducted by means of the R-project Statistical Software (R Core Team, 2017).

For the statistical evaluation of the data, we used standard measures that describe variables, such as mean, standard deviation, median, minimum, and maximum per country. Appendix 1 shows the full data of 112 countries. Next, we explain the development of the methodology to test each hypothesis and also show the obtained parameters.

\section{Association of Immigrants with FDI from Spain to Their Home Countries}

Figure 1 shows the trends that reflect FDI values and the number of emigrants/immigrants over the years. This figure reveals how the higher number of immigrants is related to overall higher FDI values. In 2000-2007, the number of immigrants continued to rise and reached its peak in 2007. Moreover, FDI reached its highest overall value in 2007. From 2007, we observe a decline in the number of immigrants, along with a decrease in the value of FDI.

To check whether the variation of FDI is relevantly influenced by immigrants, the appropriate linear mixed model (LMM) was calibrated to fit the FDI values. The model specification was determined by the inclusion of intra-country random effect and adjusted by the use of a polynomial function of time and the immigrants' absolute number. A statistically significant association between immigrants and FDI was found ( $p$-value=0.0054). It appears that the increase in the number of immigrants also leads to an increase in FDI values. In general, we may say that an increase in the absolute number of immigrants by one unit results in the simultaneous increase in FDI of $\$ 12.7(3.7,21.6)$.

\footnotetext{
Iraq, Iran, Ireland, Israel, Italy, Japan, Jordan, Kazakhstan, Kenya, Latvia, Lebanon, Liberia, Liechtenstein, Lithuania, Luxembourg, Macedonia (Former Yugoslav Republic of), Mali, Malta, Mauritania, Mexico, Morocco, Moldova, Nepal, Netherlands, New Zealand, Nicaragua, Nigeria, Norway, Pakistan, Panama, Paraguay, Peru, Poland, Portugal, Czech Republic, Slovak Republic, Romania, Russia, Senegal, Serbia, Sierra Leone, South Africa, Syria, Sweden, United Kingdom, Switzerland, Thailand, Togo, Tunisia, Turkey, Ukraine, Uruguay, Venezuela, Vietnam.

${ }^{2}$ We focused on the analysis of both the pre-crisis 1998-2007 and post-crisis 2008-2016 periods.
} 
The marginal R-squared amounted to 0.012 and the conditional R-squared to 0.285 . Marginal R2 represents the variance explained by fixed factors, while Conditional R2 is interpreted as the variance explained by both fixed and random factors.

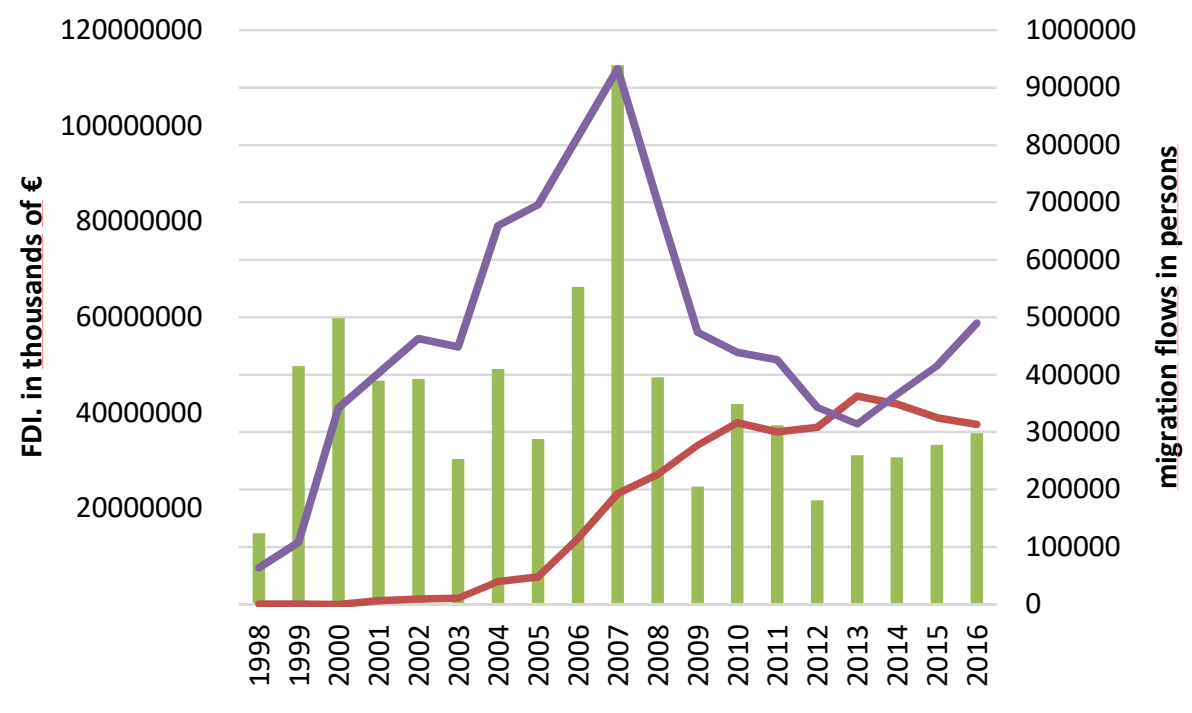

Figure 1. Changes in emigration, immigration, and FDI in Spain in 1998-2016

Source: National Statistics of Spain. INE and the Ministry of Economy and Finance of Spain.

\section{Association of Spanish Emigration and FDI from Spain to Their Host Countries}

Figure 1 also shows that the number of emigrants from Spain increases over time and that lower values are spotted when the FDI flows towards host countries. An overall increase in the number of emigrants was noticed after 2008 when there was a decline in FDI values. Therefore, we may conclude that, when the FDI was lower, there was a much higher number of emigrants. As years go by, one observes a general increase in the number of emigrants and a decrease in the value of foreign direct investment.

In order to test for a significant association of the number of emigrants and FDI, a linear mixed model was calibrated with an intra-country random effect and a fixed effect for FDI, adjusted by the polynomial function of time. The interaction term between the year and FDI emerged as significant ( $p$-value $<0.001)$.

In general, for every $\$ 100,000$ of additional FDI, there was a drop in the number of migrants by $73(-94,-52)$ per year, yet the effect of FDI on migrants every year has been reduced by $10(7,13)$ migrants (in absolute terms). Therefore, the same increase of $\$ 100,000-$ although already seven years later - had no impact on emigrants, while ten years later, when FDI decrease was spotted, the number of emigrants increased yet by 30 (in absolute terms).

In other words, we recognised how the impact of FDI on emigration changes over the years and, noteworthy, this impact was initially positive, while changing to negative in the last few years. The marginal R-squared amounted to 0.14 and the conditional R-squared to 0.69 . 


\section{RESULTS AND DISCUSSION}

As regards immigration and FDI, a significant and positive association was found, which concurrently confirms hypothesis 1 . In a nutshell, this means that more immigration into Spain goes hand in hand with more Spanish FDI in the sending countries. Noteworthy, Spain received a very large number of immigrants in 1998-2007 (Mihi-Ramirez, 2013). Moreover, Spanish international FDI flow towards migrants' origin countries increased progressively, especially during the economic expansion (Datainvex, 2018). However, since the time of the great economic recession, this trend has been reversed, meaning that immigration sharply decreased and FDI also followed suit. This whole process repeated itself in the same way, yet with less intensity, as soon as the first signs of economic improvement emerged (see Figure 1). The results confirm that migration and FDI are complementary, which agrees with earlier results presented by Russell and Teitelbaum (1992), Docquier and Lodigiani (2010), Gheasi et al. (2013), Metelski and Mihi-Ramirez (2015), Jayet and Marchal (2016), and Comolli (2018). However, our study brings additional empirical evidence to support the existence of the impact of immigration on FDI, which is based on a wide international sample for different economic phases of the last economic cycle. Furthermore, our study confirms that immigration and FDI between Spain and recipient countries of Spanish FDI does not necessarily fail to withstand the test of time. In other words, the above-mentioned relation between migration and FDI might be sustained in the long run, as opposed to what was often raised in classical approaches (e.g. Neoclassical, Push-Pull, World-Systems, or Heckscher-Ohlin).

Referring to both the literature on migration and our results, we can say that immigration and FDI are two sides of the same coin.

Perhaps in some cases, the main objective of FDI is to ensure initial production capacity in less developed countries, mainly in order to allow the proper flow of supplies. However, we should not overlook that immigration links with sending countries (countries of origin) also encourage FDI inflows into these countries, which in the long run are beneficial for both sending and receiving countries, for at least several reasons. That is, because of the sharing of technology and knowledge, because of cost reductions and new business opportunities, and because of increased market participation and access to more skilled human capital (Mihi-Ramirez, 2013; Castles \& Miller, 2009; Burns \& Mohapatra, 2008).

In this sense, if we consider the evolution of migration policy in Spain, it consists essentially of several regularisation programmes over the years, according to domestic demand for labour and the specificity of the labour market (Mihi-Ramirez, 2013), but the impact of immigration on FDI has been barely taken into account in the design of such policies. A number of initiatives have emerged at the European level to encourage the integration of migrants but - after the fiscal pressures of the recession - the integration processes weakened.

Therefore, we propose the promotion of a more proactive migration policy that supports not only migrants' integration in host countries but also their return to home countries in order to ensure that these countries have sufficient qualified human capital to support new technologies, knowledge, and innovation. There are some successful examples 
of building and implementing a strategy for international students, which ensure their return to their home countries, such as the agreement between China and Australia, Canada, or the USA; to name but a few (Hawthorne, 2010).

Moreover, we should also encourage FDI inflows into sending countries. In this sense, trade agreements are an excellent tool, whether or not they involve selective FDI in more productive and critical sectors - especially at the European level, as in the case of Spain - to take advantage of the huge interconnections of the European Union. Furthermore, such agreements would be more effective if they covered free movement programmes and facilitated business initiatives.

In relation to FDI and emigration from the investing countries, we observed a certain negative phenomenon, which actually confirms hypothesis 2. Migration has traditionally been understood as the movement of people from less developed countries to more developed countries, but we should also remember that the economic situation is never static and constantly changing, depending on socio-economic conditions, as demonstrated, for example, by the case of Spain during the recent major recession, which led to internal devaluation. Moreover, it has worsened the situation of FDI and migration from Spain to countries with Spanish FDI.

With regard to the concept known in the literature as the new economics of labour migration, traditional migration from sending countries can be explained in terms of collective actions, but also from the perspective of diversification of income through remittances sent abroad by family members (Stark, 1991). However, the countries responsible for FDI may consider migration as a good strategy for risk aversion, asset accumulation, and diversification of investments in different countries, which helps companies and countries in difficult times. Moreover, migration also creates new opportunities and ties with host countries, which makes such countries attractive to Spanish migrants in the event of economic disruptions.

Furthermore, we may combine this approach with the migration decision-making theory (Sell \& DeJong, 1978). De Jong and Gardner (1981) argue that people tend to move to the places where the benefits of the below factors are the greatest. Migration decisionmaking theory shows that greater benefits depend on a multiplicative interaction of four variables: (1) availability, (2) motive, (3) expectancy, and (4) incentive. We can extend this approach to companies and governments' decisions on FDI:

- Availability (this applies especially to the cognitive and physical possibility to invest or migrate);

- Motive (it evaluates firms and country circumstances related to the decision-making process, e.g. economic situation);

- Expectancy (evaluation of the probability of the achievement of defined objectives);

- Incentive (relates to the determinants that positively and negatively affect the change of behaviour).

FDI should be directed primarily to those places where the potential interaction between the above-mentioned four factors is the greatest. In fact, migrants are already choosing the destinations that offer the most benefits from these factors. It is conceivable that this would allow businesses and governments to interact even more with each other and better control their investment and labour mobility. 


\section{CONCLUSIONS}

This paper examines the interaction of modern international migration and FDI with particular regard to the situation before and after the great recession. It takes into account the different approaches to migration and mobility factors found in the literature. We also performed a separate analysis of emigration and immigration in order to obtain more specific and precise results by using relatively new data that cover the period 1998-2016 in 112 countries.

Our study confirms the existence of a relationship between sending and receiving countries in terms of immigration, emigration, and FDI. This link changes over time in the same economic conditions. In a way, Spain is an excellent example here, since it went from a state of great expansion to a very drastic recession, which caused a serious damage to the economy.

We raised the question whether an increase in the number of immigrants in Spain leads to an increase in FDI flows towards origin countries (i.e. sending migrants). Our results show that, in the period before the economic crisis, the huge wave of immigration to Spain was also accompanied by a larger Spanish FDI in the countries of immigrants' origin. However, when the recession began, immigration to Spain suddenly ceased, and the same happened to Spanish FDI in the countries of origin.

It means that immigration and FDI are complementary. Our work provides empirical evidence based on a multinational statistical sample and shows that immigration affects FDI in today's economy. Furthermore, our study confirms that the association between immigration and FDI persist in the long run, withstanding the test of time.

As opposed to classical approaches (e.g. Neoclassical, Push-Pull, World-Systems, or Heckscher-Ohlin), international migration and FDI flows never cease to exist, yet their progress and benefits may vary according to the socio-economic situation. Therefore, our proposal is to create and implement more proactive migration policies that would facilitate migrants' integration into host countries, but that would also have a positive impact on migrants' returns home, so that a sufficient stock of skilled human capital is maintained in origin countries to absorb and leverage the benefits of received FDI. Another practical recommendation is the use of trade agreements reinforced by free movement programmes and entrepreneurship initiatives, particularly in critical and productive sectors. In this context, it is important to recall the growing problem of labour market ageing in developed countries. Migration could increase labour market participation in these countries.

We also formulated the question whether Spanish emigrants choose those countries as their migration destinations where Spanish FDI is traditionally higher. Indeed, our results show that migration from Spain increases when FDI falls.

Economic growth is changing over time and even developed economies must provide an appropriate risk aversion strategy for their investments (in other countries) and encourage their citizens to invest in origin countries so that they can possibly maximise their return on capital from such investments.

Therefore, we propose that - in their FDI decisions - companies and governments use a method that results from the (factored in) migration decision-making theory in order to concentrate FDI in these locations where the sum of benefits is the greatest for migrants, companies, and governments. 


\section{Limitations and Future Research Lines}

With regard to FDI, the literature distinguishes between "vertical" and "horizontal" foreign investments models. This paper does not make such a distinction so as to cover several theoretical approaches to the subject and also because we focus exclusively on the case of Spain. At the same time, we propose this as a future line of research, which could boil down to analysing a sample of a subgroup by relying on relative factor endowment differences and similarities in migrants' origin countries.

Another important distinction in the literature on migration concerns the level of education. Studies so far have shown that an analysis of this level could produce more precise results, thus showing significant differences. Therefore, as another future line of research, we propose to study the level of educational achievements.

\section{REFERENCES}

Aroca, P., \& Maloney, W. (2005). Migration, Trade, and Foreign Direct Investment in Mexico. World Bank Economic Review, 19(3), 449-472. https://doi.org/10.1093/wber/lhi017

Aubry, A., Kuglerb, M., \& Rapoport, H. (2012). Migration, FDI and the Margins of Trade, Migration. International Capital Flows and Economic Development. Boston University: Harvard University.

Bijak, J. (2010). Forecasting international migration in Europe: a Bayesian view. The Springer Series on Demographic Methods and Population Analysis. SpringerScience+Business Media B.V, 24.

Breitenfellner, A., \& Cuaresma, J. (2008). The Impact of EU Enlargement in 2004 and 2007 on FDI and Migration Flows Gravity Analysis of Factor Mobility. Monetary Policy and the Economy, Oesterreichische Nationalbank (Austrian Central Bank), 2(8), 101-120.

Buch, C., Kleinert, J., \& Toubal, F. (2006). Where Enterprises Lead, People Follow? Links between Migration and German FDI. European Economic Review, 50(8), 2017-2036.

Burda, M. (2004). Factor Reallocation in Eastern Germany after Reunification. The American Economic Review, 96(2), 368-374. https://doi.org/10.1257/000282806777211748

Burns, A., \& Mohapatra, S. (2008). International Migration and Technological Progress. World Bank, Washington, DC: World Bank.

Castles, S., \& Miller, M.J. (2009). The Age of Migration: International Population Movements in the Modern World. Basingstoke: Palgrave Macmillan (4th edition).

Clark, J., \& Pearson, D. (2007). Economic freedom, entrepreneurship, migration and economic growth. Clarion Business and Economic Review, 6(2), 10-23.

Combes, J., Kinda, T., \& Plane, P. (2005). Capital Flows, Exchange Rate Flexibility, and the Real Exchange Rate. IMF Working Paper, 11, 1-34.

Comolli, P. (2018). Correction to: Migration, FDI, and Welfare. Atlantic Economic Journal, 46(3), 355-355. https://doi.org/10.1007/s11293-018-9579-5

Cuadros, A., Martín-Montaner, J., \& Paniagua, J. (2016). Homeward bound FDI: Are migrants a bridge over troubled finance? Economic Modelling, 58, 454-465. https://doi.org/10.1016/j.econmod.2016.05.021

D’Agosto, E., Solferino, N., \& Tria, G. (2006). The Migration and FDI Puzzle: Complements or Substitutes? Centre for Economic and International Studies Working Paper No 76, Rome.

Datainvex. (2018). Statistic of Spanish foreign direct investment, Ministry of Economy and Finance of Spain. Retrieved from http://datainvex.comercio.es/ on December 12, 2018. 
De Haas, H. (2010). Migration and Development: A Theoretical Perspective. International Migration Review, 44, 227-264. https://doi.org/10.1111/j.1747-7379.2009.00804.x

De Simone, G., \& Manchin, M. (2012). Outward migration and inward FDI: factor mobility between eastern and western Europe. Review of International Economics, 20(3), 600-615. https://doi.org/10.1111/j.1467-9396.2012.01041.x

Dicken, P. (2003). Global Shift: Reshaping the Global Economic Map in the 21st Century. London: Sage.

Docquier, F., \& Lodigiani, E. (2010). Skilled migration and business networks. Open Economies Review, 21(4), 565-588.

Eurostat. (2019). Foreign direct investments. Retrieved from https://ec.europa.eu/eurostat/web/structural-business-statistics/global-value-chains/fdi on February 13, 2019.

Flisi, S., \& Murat, M. (2011). The hub continent. Immigrant networks, emigrant diasporas and FDI. The Journal of Socio-Economics, 40, 796-805. https://doi.org/10.1016/j.socec.2011.08.025

Gandolfi, D., Halliday, T., \& Robertson, R. (2017). Trade, FDI, migration, and the place premium: Mexico and the United States. Review of World Economics, 153(1), 1-37.

Gardiner, J., Luo, Z., \& Lee A. (2009). Fixed effects, random effects and GEE: What are the differences? Statistics in Medicine, 28, 221-239. https://doi.org/10.1002/sim.3478

Gheasi, M., Nijkamp, P., \& Rietveld, P., (2013). Migration and foreign direct investment: education matters. Annals of Regional Science, 51(1), 73-87.

Gould, D.M. (1994). Immigrant Links to the Home Country: Empirical Implications for U.S. Bilateral Trade Flows. Review of Economics and Statistics, 76, 302-316.

Grogger, J., \& Hanson, G. (2011). Income maximization and the selection and sorting of international migrants. Journal of Development Economics, 95(1), 42-57.

Hawthorne, L. (2010). How Valuable is "Two-Step Migration"? Labour Market Outcomes for International Student Migrants to Australia Asian and Pacific. Migration Journal, 19(1), 5-36.

INE. (2018). Migration statistics (2018), National Statistics of Spain. Retrieved from www.ine.eson on November 11, 2018.

Javorcik, B., Özdenc, Ç., Spatareanud, M., \& Neaguc, C. (2011). Migrant networks and foreign direct investment. Journal of Development Economics, 94(2), 231-241. https://doi.org/10.1016/j.jdeveco.2010.01.012

Jayet, H., \& Marchal, L. (2016). Migration and FDI: Reconciling the standard trade theory with empirical evidence. Economic Modelling, 59, 46-66. https://doi.org/10.1016/j.econmod.2016.06.019

Kurekova, L. (2011). Theories of migration: Conceptual review and empirical testing in the context of the EU East-West flows, in Interdisciplinary conference on Migration. Economic Change, Social Challenge, April 6-9, University College, London: Central European University.

Le, T., \& Tran-Nam, B. (2018). Relative costs and FDI: Why did Vietnam forge so far ahead? Economic Analysis and Policy, 59, 1-13. https://doi.org/10.1016/j.eap.2018.02.004

Malan, F.A. (2015). Complementarity between FDI and migration: Using the fall of the Berlin Wall as a natural experiment. IFAC-PapersOnLine, 48(24), 201-206.

Mallampally, P., \& Sauvant, K.P. (1999). Foreign Direct Investment in Developing Countries Finance and Development. Finance and Development, 36, 34-37. https://doi.org/10.1080/00220389708422501

Markusen, J. (1983). Factor Movements and Commodity Trade as Complements. Journal of International Economics, 14(3-4), 341-356. https://doi.org/10.1016/0022-1996(83)90009-0

Massey, D.S., Arango, J., Hugo, G., Kouaouci, A., Pellegrino, A., \& Taylor, J.E. (1993). Theories of International Migration: A Review and Appraisal. Population and Development Review, 19(3), 431-466.

Metelski, D., \& Mihi-Ramírez, A. (2015). The Economic Impact of Remittances and Foreign Trade on Migration. Granger-Causality approach. Inzinerine Ekonomika-Engineering Economics, 26(4), 364-372. https://doi.org/10.5755/j01.ee.26.4.12464 
Mihi-Ramirez, A. (2013). The New Migration Flow an Analysis of Economic Factors of Poland and Spain. Journal Equilibrium. Quarterly Journal of Economics and Economic Policy, 8(2), 117-127. https://doi.org/10.12775/EQUIL.2013.009

Mundell, R. (1957). International Trade and Factor Mobility. The American Economic Review, 47(3), 321-335.

Munemo, J. (2017). Foreign direct investment and business start-up in developing countries: The role of financial market development. The Quarterly Review of Economics and Finance, 65, 97106. https://doi.org/10.1016/j.qref.2016.08.010

Phyo, E.E., Goto, H., \& Kakinaka, M. (2019). International migration, foreign direct investment, and development stage in developing economies. Review of Development Economics, 23(2), 940956. https://doi.org/10.1111/rode.12577

Portes, A. (1997). Immigration Theory for a New Century: Some Problems and Opportunities. International Migration Review, 31, 799-825.

Portes, A., \& Borocz, J. (1989). Contemporary Immigration: Theoretical Perspectives on its Determinants and Modes of Incorporation. International Migration Review, 23(3), 606-630. https://doi.org/10.1177\%2F019791838902300311

R Core Team. (2017). R: A language and environment for statistical computing. $R$ Foundation for Statistical Computing: Vienna, Austria. http://www.R-project.org/.

Russell, S., \& Teitelbaum, M. S. (1992). International migration and international trade, No WDP 160, Washington, D.C.: World Bank discussion papers.

Sanderson, M., \& Kentor, J. (2008). Foreign Direct Investment and International Migration: A CrossNational Analysis of Less-Developed Countries. International Sociology, 23, 1985-2000. https://doi.org/10.1177\%2F0268580908090726

Sauvant, K.P., Mallampally, P., \& Economou, P. (1993). Foreign Direct Investment and International Migration. Transnational Corporations, 2, 33-69.

Schiff, M. (1994). How trade, aid and remittances affect international migration. Policy Research Working Paper, The World Bank International Economics Department, International Trade Division, November.

Sell, R., \& DeJong, G. (1978). Towards a Motivational Theory of Migration Decision Making. Journal of Population, 1(4), 313-335.

Tanaka, A. (2017). Foreign direct investment and temporary workers in Japan. Journal of Asian Economics, 48, 87-99. https://doi.org/10.1016/j.asieco.2016.10.004

Tomohara, A. (2017). Does immigration crowd out foreign direct investment inflows? Tradeoff between contemporaneous FDI-immigration substitution and ethnic network externalities. Economic Modelling, 64, 40-47. https://doi.org/10.1016/j.econmod.2017.03.008

UNCTAD. (2005). Major FDI Indicators, Geneva: UNCTAD. Retrieved on December 13, 2018.

Wallerstein, I. (1974). The Modern World System. Capitalist Agriculture and the Origins of the European World Economy in the 16th Century. New York: Academic Press.

Wang, M., Wong, S.M.C., \& Granato, J. (2013). The effect of foreign direct investment on international migration: does education matter? The World Economy, 36(5), 537-562.

West, B.T., Welch, K.B., \& Galecki, A.T. (2007). Linear Mixed Models. A practical Guide Using Statistical Software: Chapman \& Hall/CRC.

$\mathrm{Xu}, \mathrm{X}$., \& Sylwester, K. (2016). The effects of foreign direct investment on emigration: The roles of FDI source country, education, and gender. Economic Modelling, 55, 401-409. https://doi.org/10.1016/j.econmod.2016.03.001 
Appendix A: Table 2

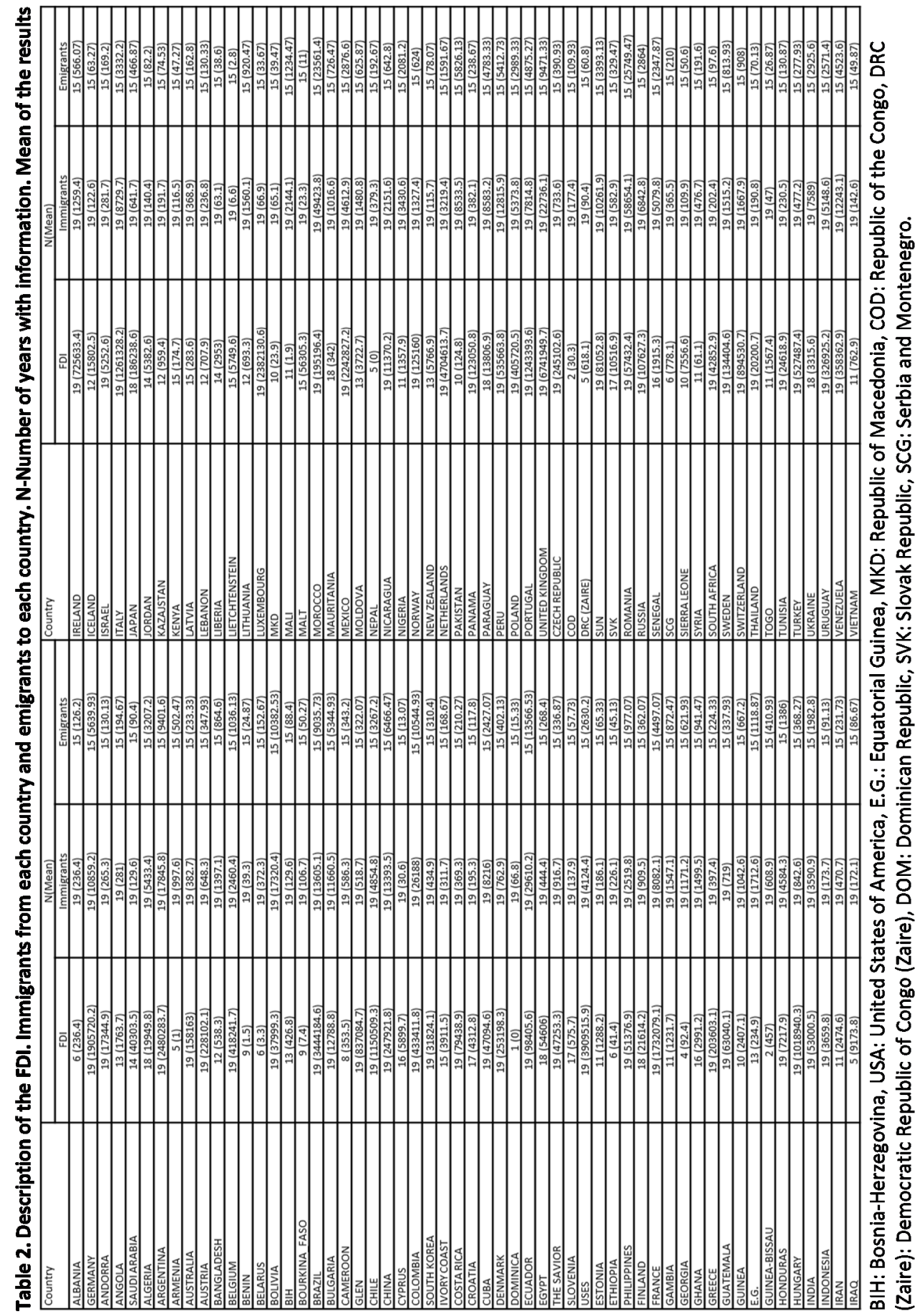




\section{Authors}

The contribution share of authors is equal and amounted to $33.33 \%$ each of them.

\section{Antonio Mihi-Ramírez}

PhD in Management (Granada University, Spain); PhD in Economics (Kaunas University of Technology, Lithuania). Professor of Department of International and Spanish Eco-nomics in Granada University. His research interests include International economics: International migration flows. Correspondence to: Prof. Antonio Mihi-Ramírez, PhD, Faculty of Economics and Management, University of Granada, 18071 Granada, Spain, e-mail: amihi@ugr.es (corresponding author).

ORCID (1) http://orcid.org/0000-0003-3801-9906

\section{Jesús Arteaga-Ortíz}

Professor of Faculty of Economics and Management, University of Las Palmas de Gran Canaria (Spain), Economics and Management Department.

Correspondence to: Prof. Jesús Arteaga-Ortíz, PhD, Faculty of Economics and Management, University of Las Palmas de Gran Canaria, Calle Juan de Quesada, 30, 35001 Las Palmas de Gran Canaria, Las Palmas, (Spain), e-mail: jesus.arteaga@ulpgc.es

\section{Sara Ojeda González}

PhD in Economics and Management, University of Las Palmas de Gran Canaria (Spain), Topics: Trade, International migration flows. Faculty of Economics and Management.

Correspondence to: Prof. Sara Ojeda González, Faculty of Economics and Management, University of Las Palmas de Gran Canaria, Calle Juan de Quesada, 30, 35001 Las Palmas de Gran Canaria, Las Palmas, (Spain), e-mail: sara.ojeda@ulpgc.es

\section{Acknowledgements and Financial Disclosure}

The article came into being within the support of the research group "Organización y dirección de empresas (Management)", University of Las Palmas de Gran Canaria (Spain).

\section{Copyright and License}

This article is published under the terms of the Creative Commons

Attribution - NoDerivs (CC BY-ND 4.0) License

http://creativecommons.org/licenses/by-nd/4.0/

Published by the Centre for Strategic and International Entrepreneurship - Krakow, Poland 